\title{
Comparative study of perinatal outcomes between pregnant women with gestational diabetes mellitus diagnosed by the new IADPSG and the old ADA criteria
}

Phelipe Guimarães de Ornellaš, Luana Verztman Bagdadi, Zuliana Bonde Almeida, Priscila de Almeida Lago, Ana Luíza Campanholo, Joana Rodrigues Dantas, Marcus Miranda dos Santos Oliveira, Melanie Rodacki, Lenita Zajdenverg

From 20th Brazilian Diabetes Society Congress

Porto Alegre, Brazil. 11-18 November 2015

\section{Background}

In 2010 the International Association of Diabetes and Pregnancy Study Group (IADPSG) suggested new values for the diagnosis of gestational diabetes mellitus (GDM). These values, also accepted in 2013 by the World Health Organization, are lower than those used previously, which resulted in an increase in the number of pregnant women with this diagnosis. It is still controversial if IADPSG/WHO criteria is cost-effective and safe.

\section{Objective}

To compare perinatal outcomes of pregnancies from women with GDM diagnosed in 2004 by the former ADA criteria with those diagnosed in 2014 by the IADPSG criteria /WHO.

\section{Materials and methods}

Data were collected on medical records from pregnant women with GDM who required insulin treatment followed in 2004 and in 2014 at the Maternity School of the Federal University of Rio de Janeiro (UFRJ). The criteria for indicating insulin were the same in both groups: Fasting plasma glucose (FPG) above $95 \mathrm{mg} / \mathrm{dL}$ or above $140 \mathrm{mg} / \mathrm{dL} 1$ hour postprandial, 7 days after initiation of diet therapy. It was used SPSS to perform comparative analyzes of the incidence of abortion, hypertensive disorders of pregnancy (HDP), preterm birth, birth weight and weight adequacy for gestational age between the groups.

\section{Results}

GDM diagnosis in 2014 were made only by two abnormal FPG in 36 (50.7\%) women and in 20 (28.2\%) pregnant women it would not be diagnosed by the old criteria. Women from both yrs. did not have differences on average BMI $(29.5 \times 28.6 \mathrm{Kg} / \mathrm{m} 2 ; \mathrm{p}=0.10)$ nor in age ( $30.3 \times 32.0$ yrs.; $\mathrm{p}=0.16)$. Among the 28 patients analyzed in 2004, 7 (25\%) of them delivered a newborn large for gestational age (LGA), while in 2014, the 71 analyzed patients, $3(4.2 \%)$ had LGA infants; $\mathrm{p}<0.001$. The mean weight of newborns in 2004 was 3575 grams, while in 2014 was 3181 grams; $\mathrm{p}<0.001$ There were no statistical differences between abortions, HDP and prematurity rates.

\section{Conclusion}

The findings of this retrospective study in which we compared maternal and fetal endpoints based on two different diagnostic criteria indicates that in women with GDM treated with insulin, intervention is more effective in those diagnosed through the new criteria proposed by IADPSG/WHO. We concluded that diagnose DMG using a higher sensitivity test improves weight parameter of newborns.

* Correspondence: ornellasphelipe@gmail.com

Universidade Federal do Rio de Janeiro, Rio de Janeiro, Brazil 
Submit your next manuscript to BioMed Central and take full advantage of:

- Convenient online submission

- Thorough peer review

- No space constraints or color figure charges

- Immediate publication on acceptance

- Inclusion in PubMed, CAS, Scopus and Google Scholar

- Research which is freely available for redistribution

Submit your manuscript at www.biomedcentral.com/submit
() Biomed Central 